To Cite: Yigit A, Menges N, Alma MH, Akinay Y,2021. Design, Synthesis and Antimicrobial Activities of New Carbon Nanotubes Derivatives. Varieties. Journal of the Institute of Science and Technology, 11(2): 1420-1429.

\title{
Design, Synthesis and Antimicrobial Activities of New Carbon Nanotubes Derivatives
}

\author{
Aybek YİGİT ${ }^{1 *}$, Mehmet Hakki ALMA ${ }^{3}$, Yüksel AKİNAY ${ }^{4}$, Nurettin MENGES $^{2}$
}

\begin{abstract}
Even though natural products or crops have been more common and popular in the recent, the chemicals without side-effects have been also addressed in various fields of industries due to possibility obtaining the large quantity and more bio-efficacy. In that context, many drugs have been developed for antibacterial activities but the over-uses of those relevant drugs have caused that microorganisms have adapted and evolved resistance against those drugs. Those lead to the researchers to focus on newly synthesized or functionalized molecules. In that context, nanotechnology, especially modified nanocarbon tubes (NCTs), are of the great interest of the various industries. Along with the current study, multi-walled carbon nanotubes (MWCNTs) were functionalized with three steps. Firstly, the carbon nanotube with a carboxylic acid tip on its surface was commercially purchased and then converted into acyl chloride, and later converted into a more reactive group. Then, the nucleophilic amino group such as diethylene triamine is bonded onto the carbon nanotube. Finally, after the carbon nanotube material with amine groups was functionalized with boric acid, carbon nanotube molecules carrying boric acid molecules were synthesized. Following modification and functionalization of MWCNTs, the newly synthesized molecules were characterized using FT-IR, SEM, TEM and XPS. After chemical characterization, the relevant molecules were screened for their anti-bacterial activities in comparison to those of well-known antibiotics. For anti-bacterial assays, molecules were tested against K. pneumoniae, E. coli, P.aeruginosa, S. aureus and B. subtilis. Concerning the findings of the antibacterial assays, concentrations of 40 and $80 \mu \mathrm{g} / \mathrm{mL}$ exhibited a range of activities but in parallel with those of standard antibiotics whereas the lower concentration, viz. 5, 10 and $20 \mu \mathrm{g} / \mathrm{mL}$ did not exhibit any activities. The highest activity was noted for $80 \mu \mathrm{g} / \mathrm{mL}$, in comparison to those of antibiotics and other concentrations, against B. subtilis, with a $23 \mathrm{~mm}$ inhibition zone.
\end{abstract}

Keywords: Carbon nanotube, disc diffusion method, primary amine, antibacterial activity

\footnotetext{
${ }^{1}$ Aybek YIGIT (Orcid ID: 0000-0001-8279-5908), Application and Research Center, Igdir University, Igdir, Turkey,

${ }^{2}$ Nurettin MENGES (Orcid ID: 0000-0002-5990-6275), Pharmaceutical Chemistry Section, Van Yüzüncü Yil University, Van, Turkey

${ }^{3}$ Mehmet Hakki ALMA (Orcid ID: 0000-0001-6323-7230), Department of Biosystem Engineering, Igdir University, Igdir, Turkey

${ }^{4}$ Yüksel AKINAY (Orcid ID: 0000-0002-6171-6307), Faculty of Engineering and Architecture, Department of Mining Engineering, Van Yüzüncü Yil University, Van, Turkey

*Corresponding Author: Aybek YİĞİT, e-mail: aybek.yigit@igdir.edu.tr
} 
Design, Synthesis and Antimicrobial Activities of New Carbon Nanotubes Derivatives

\section{INTRODUCTION}

Infectious diseases have been of the main causes of death due to enhanced resistance of bacteria to drugs available which, in turn result in higher rate of morbidity and mortality (Allahverdiyev et al., 2011). The relevant evolved resistance of the bacteria has been attributed to excessive uses of the current available drugs, causing a big and substantial threat to the health worldwide. To be compatible with the possible emergence of increasing global alarming of microbial diseases or to develop new compounds with augmented biological activities are of the great concerns. Furthermore, the well-known compounds might be also improved in their biological activities with the nanotechnology, especially modified nanocarbon tubes (NCTs) (Khabashesku et al., 2006; Amiri et al., 2012; Aslan et al., 2012; Zardini et al., 2012; Mocan et al., 2014; Salam et al., 2017; Sah et al., 2018). Indeed, a very high antibacterial activity of carbon based nanoparticles has been well-known and disseminated in that context. Of the first relevant researches, fullerenes, single-walled CNTs and graphene oxide (GO) nanoparticles have been clearly reported to possess anti-bacterial activities toward pathogenic microorganisms (Sah et al., 2018). However, in the last decades, allotropes of this new carbon have been discovered and applied in many fields (Sokolov and Stankevich, 1993; Cataldo and Da Ros, 2008; Wang et al., 2014).

A newly synthesized, modified and consequently functionalized carbon-based material are, in general, equipped with different properties rather than other conventional materials, being exclusive in its chemical structure, tubular arrangement, modifiable surface, stability and strength (Hu et al., 2009; Sah et al., 2018). Herewith the acquired unique and distinguishable properties, CNTs are of the mostly investigated allotropes of carbon, being prime candidates to be assessed in various disciplines ranging from medicine (Eatemadi et al., 2014; Amenta and Aschberger, 2015; Alshehri et al., 2016) to agriculture (Mondal et al., 2011; De La Torre-Roche et al., 2013; Chhipa, 2017).

Specifically, in order to combat with the possible emergence of new infectious diseases or their variants or microbial problems available, a wide range arrays of studies relating with enhancing the antibacterial capacity of the conventional compounds have been great interest studied (Chen et al., 2013; Seo et al., 2014; Dizaj et al., 2015; Kassem et al., 2019). For that reason, in the current study, we assessed the antibacterial activities of functionalized MWCNTs using diethylene triamine and boric acid. The structural modifications were revealed using FT-IR, SEM, TEM and XPS. Then, the successfullyobtained and conjugated compounds were assayed for their activity with five different microorganisms such as K. pneumoniae, E. coli, P.aeruginosa, S. aureus and B. subtilis. Then, compared with the common and well-known standard antibiotics Entamicin, Erythromycin, Amikacin, Ampicillin, and Cloxacill.

\section{MATERIALS AND METHODS}

\section{Functionalization and Characterization Materials}

Thionyl chloride $\left(\mathrm{SOCl}_{2}\right)$, dimethylformamide (DMF), anhydrous tetrahydrofuran (THF), Diethylene Triamine, and boric acid were purchased from Sigma-Aldrich. Multi-walled carbon nanotubes (MWCNTs) were purchased from Nanografi Nano Technology with -COOH Functionalized MWCNT, Purity $>96 \%$, Outside Diameter: average diameters of 8-18 nm.

\section{Functionalization of MWCNTs with Acylchloride}

Figure 1 shows the schematic diagram of the surface acylation of multi-walled CNT with carboxylic acid tip. Following that acylation, $100 \mathrm{mg}$ of MWCNTs (MWCNTs-COOH) was stirred in $10 \mathrm{~mL}$ of thionyl chloride $\left(\mathrm{SOCl}_{2}\right)$ in the presence of $1 \mathrm{~mL}$ of dry dimethylformamide (DMF) at $70^{\circ} \mathrm{C}$ 
for $24 \mathrm{~h}$. Then, a filtration process was followed for removal of solid from the solution using Gooch crucible (No: 3 or 4). The filtrate was firstly washed using dry diethylether, dry THF and finally with dry DMF and dried at $25^{\circ} \mathrm{C}$ temperature in a vacuum oven.

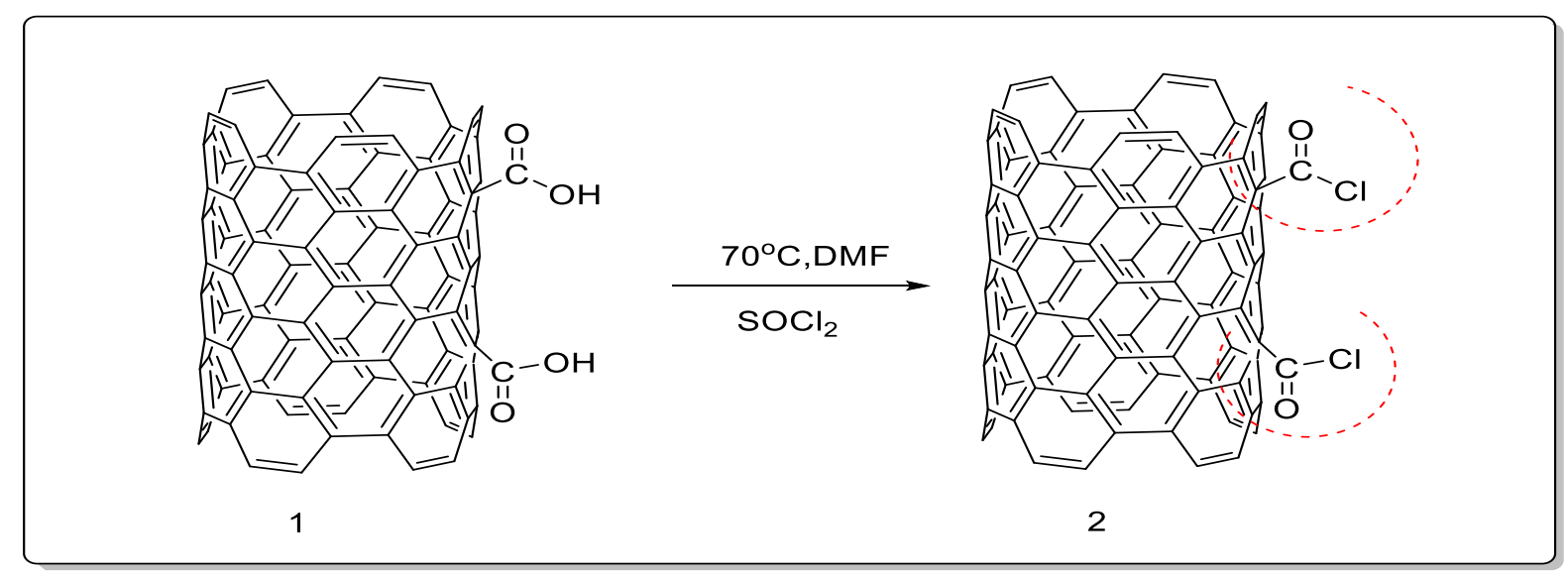

Figure 1. Schematic diagram of the surface acylation of multi-walled CNT with carboxylic acid tip

\section{Functionalization of MWCNTs with Diethylenetriamine}

Figure 2 shows the functionalization procedure of MWCNTs-Cl with diethylene triamine. In that context, MWCNTs-Cl $(250 \mathrm{mg})$ was mixed with $4 \mathrm{~mL}$ of diethylene triamine and stirred for $24 \mathrm{~h}$ at $204^{\circ} \mathrm{C}$.Then, the procedure was followed by the filtration of the resulted material for removal of solid particles from the solution. Ultimately, the filtrates were washed using dry THF and dried at $25{ }^{\circ} \mathrm{C}$ temperature in a vacuum oven.

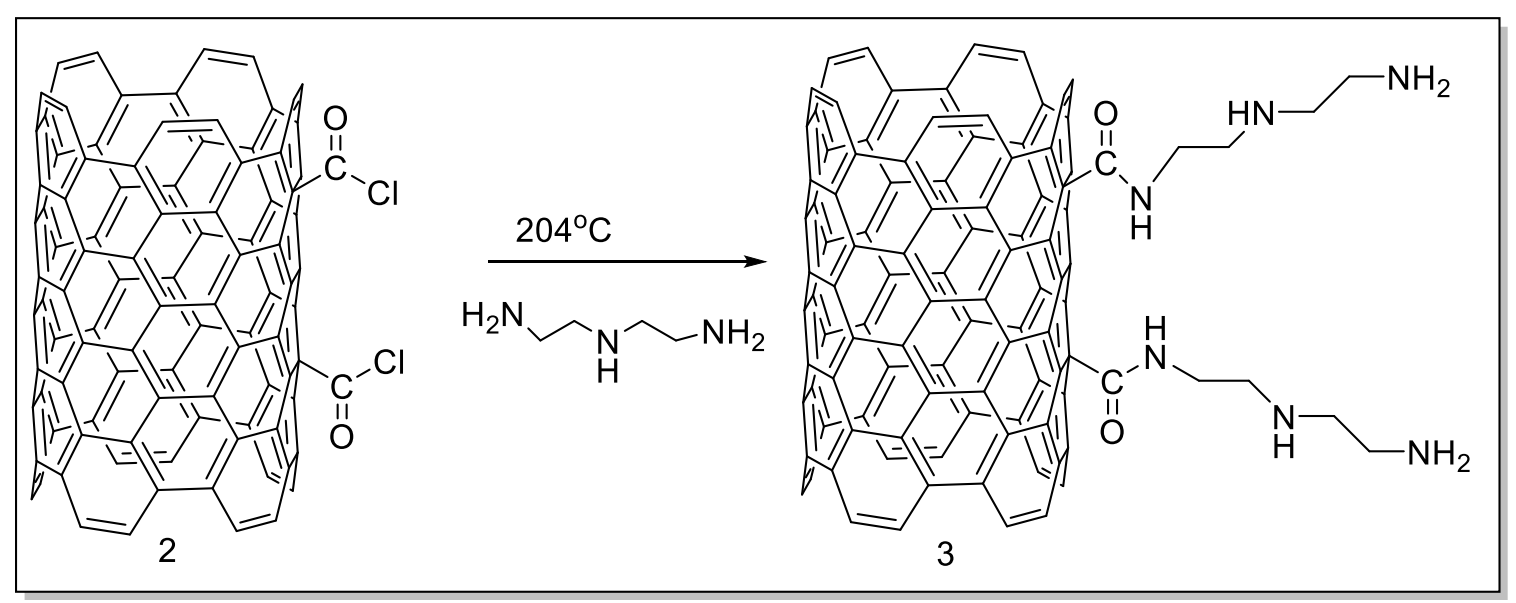

Figure 2. Schematic diagram of the tip of acylated multi-walled CNT with Diethylene Triamine groups.

\section{Functionalization of MWCNTs- $\mathrm{NH}_{2}$ with boric acid}

Figure 3 shows the functionalization procedure of $\mathrm{MWCNTs}-\mathrm{NH}_{2}$ with boric acid. Briefly, MWCNTs- $\mathrm{NH}_{2}(50 \mathrm{mg})$ was mixed with boric acid $(150 \mathrm{mg})$ in $5 \mathrm{~mL}$ dry DMF and then mixture was allowed for stirring at $150^{\circ} \mathrm{C}$ for $24 \mathrm{~h}$. The stirring was followed by the removal of solid particles from the solution using Gooch crucible (No: 3 or 4 ). The filtrate was firstly washed using pure water, THF and finally with ethyl alcohol and dried at $25^{\circ} \mathrm{C}$ temperature in a vacuum oven. 


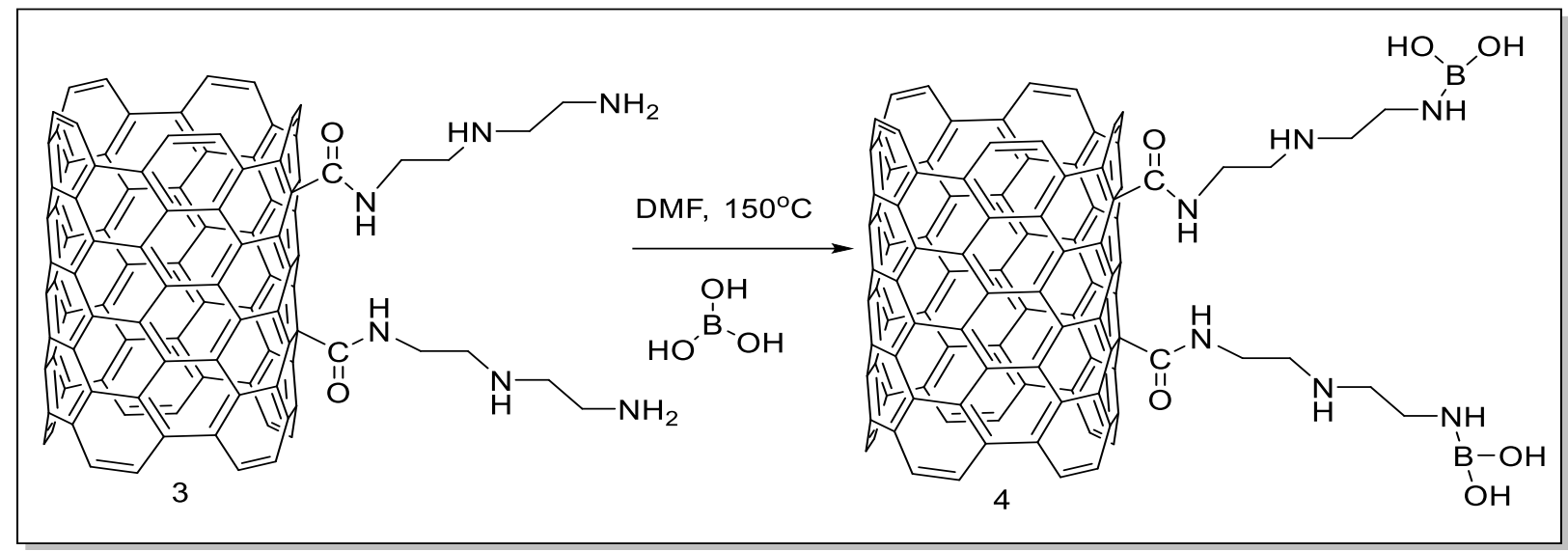

Figure 3. Schematic diagram of boric acid functionalization at the end of Diethylene Triamine modified multi-walled CNT

\section{Characterization İnstrument}

\section{FT-IR studies}

FT-IR spectra were obtained using $\mathrm{KBr}$ pellets $\left(4000-400 \mathrm{~cm}^{-1}\right)$ on Bio-Rad-Win-IR Spectrophotometer.

\section{Scanning Electron Microscope (SEM)}

The structure characterization of the samples was carried out using a Zeiss Sigma 300 scanning electron microscope (SEM) with SE detector at $10 \mathrm{kV}$ acceleration voltage.

\section{Transmission Electron Microscope (TEM)}

Hitachi HT7700 transmission electron microscope (TEM) device was used for surface information in the modification processes.

\section{X-ray photoelectron spectroscopy (XPS)}

X-ray photoelectron spectroscopy (XPS) was used to identify atomic and molecular information about the surface of the material, providing information on the composition and electrostatic level of the sample surface by analyzing the core levels and subsequent analysis of the emitted core photoelectrons. Herein, for the present study, we analyzed MWCNTs-NH-B $(\mathrm{OH})_{2}$ using XPS by taking data at a depth of $10 \mathrm{~nm}$ from the surface. The operating conditions of the spectroscopy were as follows: X-ray source: AI K $\alpha$ Monochromatic (1486.68 eV), X-ray spot size: $300 \mu \mathrm{m}$, sampling area: 60x60 mm, analyzer: 180 ${ }^{\circ}$ hemispherical analyzer-128 channel detector, $200 \mathrm{eV}$ transition energy for general scanning and $50 \mathrm{eV}$ transition energy for partial scanning, Scan number: XPS device surface analysis was performed in 3 operating parameters.

\section{Antimicrobial Studies}

\section{Microorganisms}

The microorganisms were kindly provided from bacterial collection of Van Dursun Odabaş Medical Faculty Hospital (Van, Turkey). Three of the test microorganisms were Gram-negative bacteria (Klebsiella pneumoniaee AATC 13883, Escherichia coli ATCC 36218, Pseudomonas aeruginosa ATCC 9027), and two Gram-positive bacteria (Staphylococcus aureus ATCC 25923, ATCC 6633 B. subtilis) were assayed for anti-bacterial activities. For comparison of the functionalized MWCNTs with the standard and common antibiotics, Gentamicin, Erythromycin, Amikacin, Ampicillin, and Cloxacill were used as positive control groups. DMSO (Dimethylsulfoxide) was used as a negative control group 
Design, Synthesis and Antimicrobial Activities of New Carbon Nanotubes Derivatives

for antibacterial activity assays. Disk diffusion and hollow agar methods were used to determine the antimicrobial activities of multi-walled CNTs in which amine groups and different functional groups function. In the negative control group, in order to determine the effect of dimethyl sulfoxide (DMSO) used on microorganisms, four different concentrations $(5,10,15$ and $20 \mu \mathrm{l})$ were studied and no activity was found.

\section{Determination of antibacterial activity by disk diffusion method}

For the activity studies, microorganisms kept at $-30^{\circ} \mathrm{C}$ were activated, then inoculated into $\mathrm{MHB}$ liquid medium with the help of a loop in a sterile cabinet and left for 24 hours incubation at $37^{\circ} \mathrm{C}$ (Anar et al., 2016). The bacterial suspension prepared at the end of the period was adjusted according to the Mac Farland standard density (İlçim et al., 1998; Berber et al., 2013). The discs used in the disc diffusion method (Whatman No: 1) are $6 \mathrm{~mm}$ and sterilized before use. The substances were prepared by dissolving in DMSO, and in the same way in dilutions, they were prepared with DMSO in four different concentrations $(0.025,0.05,0.1$ and $0.2 \mathrm{mg} / \mu \mathrm{l})$ and absorbed on discs. Discs were placed at equal intervals on the cultivated media. Likewise, the substances (DMSO $10 \mathrm{mg} / \mathrm{ml}$ ) were dissolved and $5 \mu 1$, $10 \mu 1,20 \mu 1,40 \mu 1$ and $80 \mu 1$ concentrations were prepared and studied in the well agar method. Furthermore, for positive control groups in their standard quantities, Gentamicin (CN: 10 $\mu \mathrm{g}$ ), Erythromycin (E: $15 \mu \mathrm{g}$ ), Amikacin (AK: $30 \mu \mathrm{g}$ ), Ampicillin (AMP: $10 \mu \mathrm{g}$ ), Cloxacill (CX: $5 \mu \mathrm{g}$ ) were used. Then it was left at room temperature for 15 minutes and incubated at $37{ }^{\circ} \mathrm{C}$ for $24 \mathrm{~h}$. After incubation, the results were measured in $\mathrm{mm}$, inhibition diameters around the cavity and discs (Onbaş11 et al., 2011).

\section{RESULTS AND DISCUSSION}

\section{FT-IR studies}

Herein, the relevant functional groups of MWCNTs-NH-B $(\mathrm{OH})_{2}$ we used for the present study were evaluated using FT-IR spectroscopy. Figure 4 shows that the spectra of MWCNTs-NH-B $(\mathrm{OH})_{2}$, revealing that $3365 \mathrm{~cm}^{-1}$ vibration band $(\mathrm{N}-\mathrm{H})$ groups, Carbonyl $(\mathrm{C}=\mathrm{O})$ groups in vibration band amide groups of $1678 \mathrm{~cm}^{-1}, 1427,1365,921 \mathrm{~cm}^{-1}$ vibration band (B-O) groups, and $920 \mathrm{~cm}^{-1}$ vibration band (C = C) groups (Amiri et al., 2012).

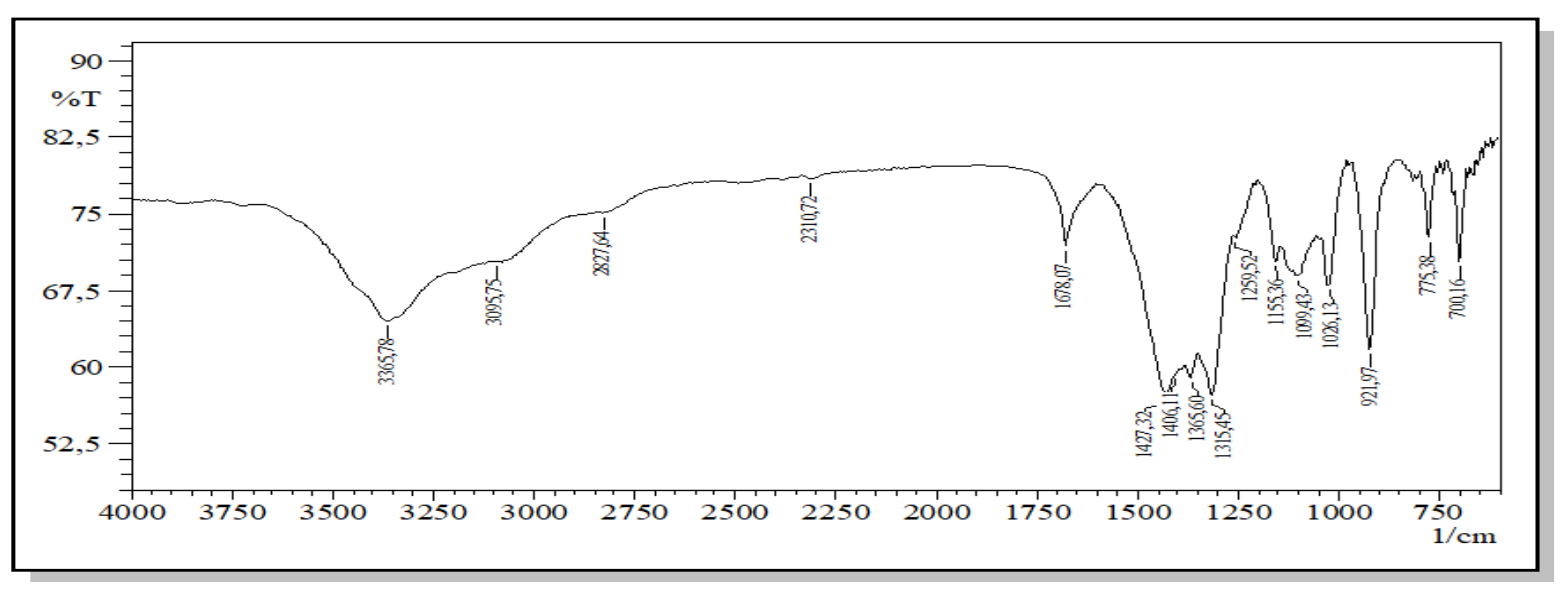

Figure 4. FT-IR spectra of MWCNTs-NH-B $(\mathrm{OH})_{2}$

\section{Scanning Electron Microscope (SEM)}

Figure 5 a-b represents the SEM images of MWCNTs- $\mathrm{NH}_{2}, \mathrm{MWCNTs-NH-B}(\mathrm{OH})_{2}$ molecules, respectively, suggesting a diameter of the multi-walled carbon nanotube modified with the amine group varied between 1-2 micrometers (Figure 5 a). Herein, a homogenous, clear and transparent image on the 
Design, Synthesis and Antimicrobial Activities of New Carbon Nanotubes Derivatives

surface of the MWCNT due to the covalently bonded amine group was observed. In addition, functionalization of CNTs with amine group resulted in contraction. Regarding modification with boric acid, the diameter of MWCNTs-NH-B $(\mathrm{OH})_{2}$ obtained through functionalization with boric acid on MWCNTs- $\mathrm{NH}_{2}$ was slightly smaller than MWCNTs-NH $\mathrm{NH}_{2}$ and a more rough surface was observed (Figure 5 b) (Cao et al., 2020)
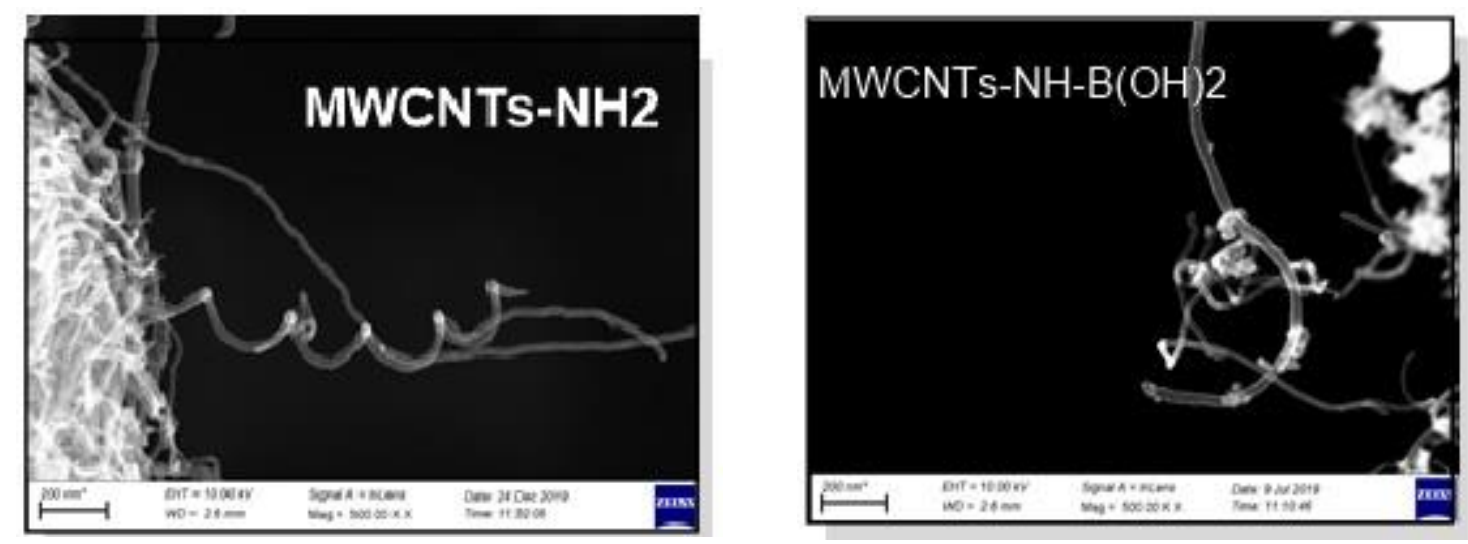

Figure 5. SEM images of MWCNTs-NH $\mathrm{N}_{2}$ and MWCNTs-NH-B $(\mathrm{OH})_{2}$ molecules

\section{Transmission Electron Microscope (TEM)}

EM images of MWCNTs-NH $\mathrm{N}_{2}$, and MWCNTs-NH-B $(\mathrm{OH})_{2}$ are given in Figure $6 \mathrm{a}-\mathrm{b}$, respectively. As seen in Figure 6 a, in the characterization, inner pore size of MWCNTs- $\mathrm{NH}_{2}$ was about an average with $10 \mathrm{~nm}$ and outer capsule size of MWCNTs- $\mathrm{NH}_{2}$ was determined as an average of 8.5$12 \mathrm{~nm}$. In addition, the inner pore size MWCNTs-NH-B $(\mathrm{OH})_{2}$ was about an average of $10 \mathrm{~nm}$ while the outer capsule size was determined to be between 8-11 nm (Cui et al., 2020).
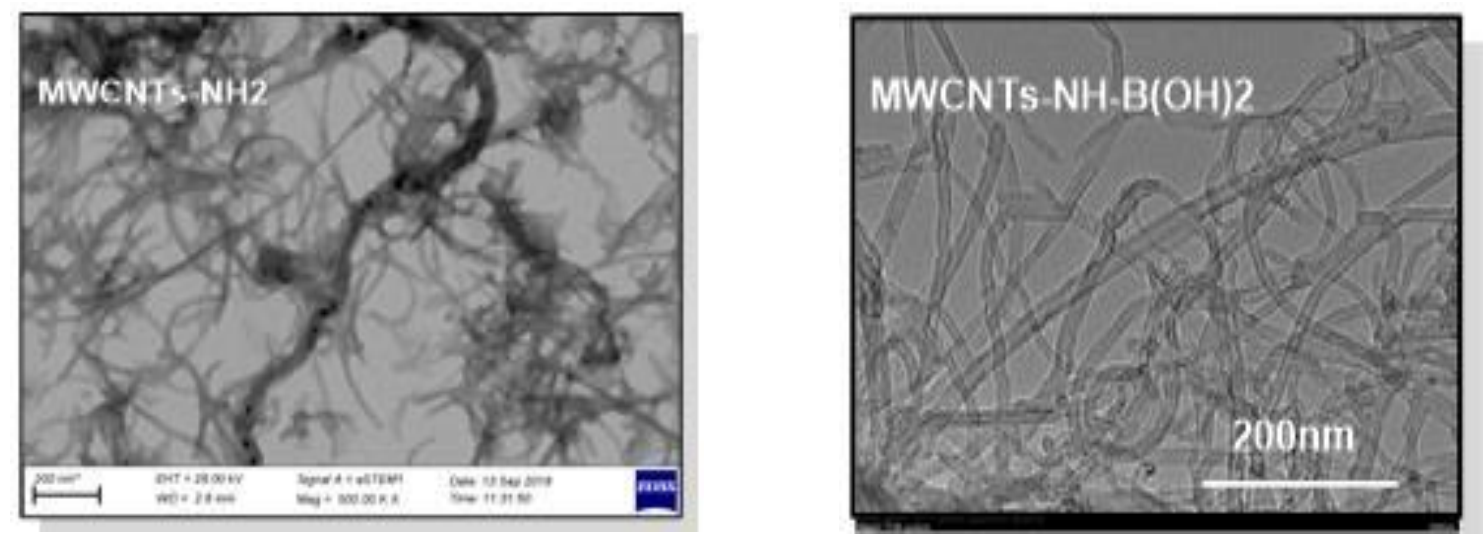

Figure 6. TEM image of MWCNTs- $\mathrm{NH}_{2}$ and $\mathrm{MWCNTs}-\mathrm{NH}_{2}-\mathrm{B}(\mathrm{OH})_{2}$.

\section{XPS analysis of MWCNTs-NH-B $(\mathrm{OH})_{2}$}

Figure 7 shows the spectra of MWCNTs-NH-B $(\mathrm{OH})_{2}$, revealing that MWCNTs-NH-B $(\mathrm{OH})_{2}$ exhibited the $\mathrm{C} 1 \mathrm{~s}$ and $\mathrm{O} 1 \mathrm{~s}$ peaks at the binding energies of 284.4 and $532.0 \mathrm{eV}$, respectively. Functionalization of MWCNTs with diethylene triamine and boric acid exhibited two new peaks of B1s and N1s at the binding energies of 192.0 and $401.0 \mathrm{eV}$, which they did not exist in MWCNTs-Cl. The deconvolution of the $\mathrm{C} 1 \mathrm{~s}$ spectra shows the following binding energy values corresponding to $284.4 \mathrm{eV}$ for $\mathrm{C}-\mathrm{C}\left(\mathrm{sp}^{2}\right) / \mathrm{C}-\mathrm{H}$ and $\mathrm{C}=\mathrm{C}, 285.19 \mathrm{eV}$ for $\mathrm{C}-\mathrm{C}\left(\mathrm{sp}^{3}\right) / \mathrm{C}-\mathrm{H}, 287.16 \mathrm{eV}$ for $\mathrm{N}-\mathrm{C}=\mathrm{O}$, and $290.76 \mathrm{eV}$ for $\pi$ $\pi$ interactions. Two peaks of $\mathrm{N} 1 \mathrm{~s}$ region demonstrate that $400.33 \mathrm{eV}$ and $401.83 \mathrm{eV}$ values are responsible 
for $\mathrm{CO}-\mathrm{NH}$ and $\mathrm{CH}_{2} \mathrm{NH}$, respectively. Presence of two different peaks in O1s region can be explained by $\mathrm{N}-\mathrm{C}=\mathrm{O}(532.13 \mathrm{eV})$ and $\mathrm{C}=\mathrm{O}$ (for carboxyl groups) $(532.91 \mathrm{eV})$. Furthermore, $\mathrm{B} 1 \mathrm{~s}$ region shows two peaks which are responsible for B-N (192.57eV) and B-OH (193.17 eV). Those relevant regional data prove that MWCNTs are properly functionalized with diethylene triamine and boric acid (Ma et al., 2014; Arumugasamy et al., 2020).

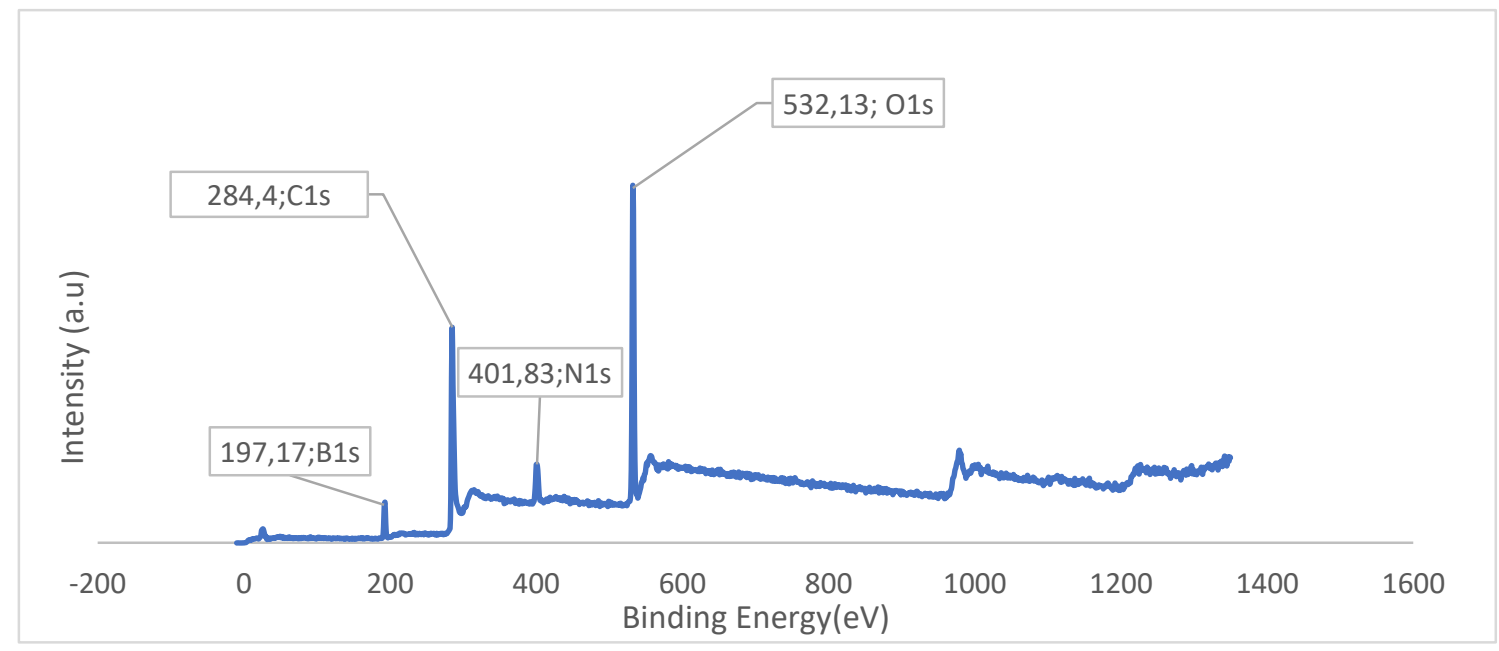

Figure 7. XPS spectrum for MWCNTs-NH-B(OH)2

\section{Anti-bacterial activities of the common antibiotics and functionalized molecules}

The findings relating activities of Gentamicin, Erythromycin, Amikacin, Ampicillin and Cloxacill are collectively presented in Table 1. Of those antibiotics, ampicilin did not exhibit any activities against P. aeruginosa and eritromisin were not substantially effective against L. monocytogenes (Table 1). For activities of MWCNTs-NH-B $(\mathrm{OH})_{2}$, a concentration ranging 5 to $80 \mu \mathrm{l}$ was bio-assayed against the pathogenic bacteria. Of the tested concentrations, only $40 \mu \mathrm{g} / \mathrm{mL}$ and $80 \mu \mathrm{g} / \mathrm{mL}$ exhibited inhibitory activities, being active against E. coli $(16 \mathrm{~mm})$ and B. subtilis $(14 \mathrm{~mm})$ at concentration of $40 \mu \mathrm{g} / \mathrm{mL}$ and E. coli $(20 \mathrm{~mm}), \mathrm{P}$. aeruginosa $(15 \mathrm{~mm}), \mathrm{S}$. aureus $(18 \mathrm{~mm})$, and B. subtilis $(23 \mathrm{~mm})$ at concentration of $80 \mu \mathrm{g} / \mathrm{mL}$ (Table 2). The tested concentrations of the molecules ranged similar inhibition zones with those of relevant antibiotics. The highest activity was noted for $80 \mu \mathrm{g} / \mathrm{mL}$, in comparison to those of antibiotics and other concentrations, against B. subtilis, with a $23 \mathrm{~mm}$ inhibition zone, leading more researches to be addressed on the inhibitory activities of the molecules against B. subtilis.

In the relevant reports, functionalized MWCNTs were more effective against E. coli than S. aureus (Zardini et al., 2012). Those results are consistent with the present findings. Lysine functionalized MWCNTs were also assayed against Escherichia coli and Klebsiella pneumonia, being bactericidal on both microorganisms whereas MWCNT- NH-B $(\mathrm{OH})_{2}$ did not exhibit any inhibitory effects on K. pneumonia (Amiri et al., 2012). We should herein utter that the volume and concentration of each solution of the present study was higher than those of Amiri et al. (2012). Those findings suggest that the activity might not be dependent on concentration but related and linked with the interaction between bacterial membrane and molecules (Liu et al., 2010), electronic structure of the CNTs (Vecitis et al., 2010), size (diameter) of the CNTs (Kang et al., 2008), and nature of the target organism (Al-Jumaili et 2017). Overall, the bactericidal activity of the MWCNTs is addressed on the complete surface phenomena involving leakage of the bacterial cellular components and coupling with the relevant enzyme activations (Li et al., 1997; Sah et al., 2018). 
Design, Synthesis and Antimicrobial Activities of New Carbon Nanotubes Derivatives

Table 1: Antibacterial activities of some common antibiotics

\begin{tabular}{lccccc}
\hline Antibiotics & K. pneumoniae & E. coli & P. aeruginosa & S. aureus & B. subtilis \\
\hline Gentamisin & $17 \mathrm{~mm}$ & $17 \mathrm{~mm}$ & $18 \mathrm{~mm}$ & $18 \mathrm{~mm}$ & $18 \mathrm{~mm}$ \\
Amikasin & $10 \mathrm{~mm}$ & $20 \mathrm{~mm}$ & $25 \mathrm{~mm}$ & $16 \mathrm{~mm}$ & $11 \mathrm{~mm}$ \\
Eritromisin & $19 \mathrm{~mm}$ & $19 \mathrm{~mm}$ & $19 \mathrm{~mm}$ & $21 \mathrm{~mm}$ & $20 \mathrm{~mm}$ \\
Ampicillin & $16 \mathrm{~mm}$ & $13 \mathrm{~mm}$ & - & $24 \mathrm{~mm}$ & $14 \mathrm{~mm}$ \\
Cloxacillun & $10 \mathrm{~mm}$ & $12 \mathrm{~mm}$ & $12 \mathrm{~mm}$ & $25 \mathrm{~mm}$ & $15 \mathrm{~mm}$ \\
\hline
\end{tabular}

mm corresponds to the inhibition zone and (-) represents "no inhibition zone with $6 \mathrm{~mm}$ disc diameter"

Table 2: Antibacterial activities of MWCNT- NH-B $(\mathrm{OH})_{2}$

\begin{tabular}{lccccc}
\hline MWCNT- NH-B $(\mathbf{O H})_{2}(\boldsymbol{\mu g} / \mathbf{m L})$ & K. pneumoniae & E. Coli & P. aeruginosa & S. aureus & B. subtilis \\
\hline $5 \mu \mathrm{l}$ & - & - & - & - & - \\
$10 \mu \mathrm{l}$ & - & - & - & - & - \\
$20 \mu \mathrm{l}$ & - & - & - & - & - \\
$40 \mu \mathrm{l}$ & - & $16 \mathrm{~mm}$ & - & - & $14 \mathrm{~mm}$ \\
$80 \mu \mathrm{l}$ & - & $20 \mathrm{~mm}$ & $15 \mathrm{~mm}$ & $18 \mathrm{~mm}$ & $23 \mathrm{~mm}$ \\
\hline
\end{tabular}

$\mathrm{mm}$ corresponds to the inhibition zone and (-) represents "no inhibition zone with $6 \mathrm{~mm}$ disc diameter"

\section{CONCLUSION}

Along with the current study, MWCNTs were successfully modified with diethylene triamine and boric acid with a three-step procedure. Those relevant modifications of MWCNT- NH-B $(\mathrm{OH})_{2}$ were clearly revealed using FTIR, XPS, SEM, and TEM analysis. Functionalized molecules were then assayed for their anti-bacterial activities. At two high concentration, a range of activities were noted for specific bacterial collections but also concentration dependent activity from 40 and $80 \mu \mathrm{g} / \mathrm{mL}$ was reported herein. Novel findings of the study might be deduced as that $80 \mu \mathrm{g} / \mathrm{mL}$ concentration of the MWCNTNH-B $(\mathrm{OH})_{2}$ were more effective against $B$. subtilis, with a-23 $\mathrm{mm}$ inhibition zone, in comparison to those of common antibiotics. Those findings might lead to the more specific studies to be addressed on the inhibitory activities of the molecules against $B$. subtilis.

\section{ACKNOWLEDGMENT}

This study was funded by both Van Yüzüncü Yil University (Project Number: 2019-FDK-7816) and Igdir University (Project number: 2019-FBE-A27). Authors thank to The head of the center of Scientific and Application Center in Van Yüzüncü Yil University for spectral support. Also, bioactivity studies was made in Staff Chemical Reagent Company.

\section{Conflict of Interest}

The article authors declare that there is no conflict of interest between them.

\section{Author's Contiibutions}

NM conceived and designed the experiments, discussed the data, and wrote the manuscript. AY has progressed experiments; YA and MHA have recorded and interpreted the DTA, SEM, TEM and XPS. All authors read and approved the manuscript.

\section{REFERENCES}

Al-Jumaili A, Alancherry S, Bazaka K, Jacob M, 2017. Review on the antimicrobial properties of carbon nanostructures. Materials, 10(9): 1066. 
Allahverdiyev AM, Abamor ES, Bagirova, M, \& Rafailovich M, 2011. Antimicrobial effects of TiO2 and Ag2O nanoparticles against drug-resistant bacteria and leishmania parasites. Future microbiology, 6(8):933-940.

Alshehri R, Ilyas AM, Hasan A, Arnaout A, Ahmed F, Memic A, 2016. Carbon nanotubes in biomedical applications: factors, mechanisms, and remedies of toxicity: miniperspective. Journal of medicinal chemistry, 59(18): 8149-8167.

Amenta V, Aschberger K, 2015. Carbon nanotubes: potential medical applications and safety concerns. Wiley Interdisciplinary Reviews: Nanomedicine and Nanobiotechnology, 7(3): 371-386.

Amiri A, Zardini HZ, Shanbedi M, Maghrebi M, Baniadam M, Tolueinia B, 2012. Efficient method for functionalization of carbon nanotubes by lysine and improved antimicrobial activity and waterdispersion. Materials Letters, 72: 153-156.

Anar M, Orhan F, Alpsoy L, Gulluce M, Aslan A, Agar G, 2016. The antioxidant and antigenotoxic potential of methanol extract of Cladonia foliacea (Huds.) Willd, Toxicology and Industrial Health, 32 (4): 721-729.

Arumugasamy SK, Govindaraju SK, Yun K, 2020. Electrochemical Sensor for Detecting Dopamine Using Graphene Quantum Dots Incorporated with Multiwall Carbon Nanotubes. Appl. Surf. Sci., 145294.

Aslan S, Deneufchatel M, Hashmi S, Li N, Pfefferle LD, Elimelech M, Van Tassel PR, 2012. Carbon nanotubebased antimicrobial biomaterials formed via layer-by-layer assembly with polypeptides. Journal of colloid and interface science, 388(1): 268-273.

Berber İ, 2013. Sinop'da yetişen bazı bitkilerin metanolik ekstraktlarının antibakteriyal ve antifungal aktivitelerinin belirlenmesi. Karaelmas Science and Engineering Journal, 3(1): 10-16.

Cao Y, Mohamed AM, Mousavi M, Akinay Y, 2020. Poly (pyrrole-co-styrene sulfonate)-encapsulated MWCNT/Fe-Ni alloy/NiFe2O4 nanocomposites for microwave absorption. Materials Chemistry and Physics, 124169.

Cataldo F, Da Ros T, 2008. Medicinal chemistry and pharmacological potential of fullerenes and carbon nanotubes (Vol. 1). Springer Science \& Business Media.

Chen H, Wang B, Gao D, Guan M, Zheng L, Ouyang H, Feng W, 2013. Broad-spectrum antibacterial activity of carbon nanotubes to human gut bacteria. Small, 9(16): 2735-2746.

Chhipa H, 2017. Nanofertilizers and nanopesticides for agriculture. Environmental chemistry letters, 15(1): 1522.

Cui L, Huang H, Ding P, Zhu S, Jing W, Gu X, 2020. Cogeneration of H2O2 and OH via a novel Fe3O4/MWCNTs composite cathode in a dual-compartment electro-Fenton membrane reactor. Separation and Purification Technology, 237: 116380.

De La Torre-Roche R, Hawthorne J, Deng Y, Xing B, Cai W, Newman LA, White JC, 2013. Multiwalled carbon nanotubes and C60 fullerenes differentially impact the accumulation of weathered pesticides in four agricultural plants. Environmental Science \& Technology, 47(21): 12539-12547.

Dizaj SM, Mennati A, Jafari S, Khezri K, Adibkia K, 2015. Antimicrobial activity of carbon-based nanoparticles. Advanced pharmaceutical bulletin, 5(1): 19.

Eatemadi A, Daraee H, Karimkhanloo H, Kouhi M, Zarghami N, Akbarzadeh A, Joo SW, 2014. Carbon nanotubes: properties, synthesis, purification, and medical applications. Nanoscale research letters, 9(1): 393.

Hu C, Hu S, 2009. Carbon nanotube-based electrochemical sensors: principles and applications in biomedical systems. Journal of Sensors 2009.

İlçim A, Dığrak M, Bağcı E, 1998. Bazı bitki ekstraktlarının antimikrobiyal etkilerinin araştırılması. Turkish Journal of Biology, 22: 119-125.

Kang S, Herzberg M, Rodrigues DF, Elimelech M, 2008. Antibacterial effects of carbon nanotubes: size does matter!. Langmuir, 24(13): 6409-6413.

Kassem A, Ayoub GM, Malaeb L, 2019. Antibacterial activity of chitosan nano-composites and carbon nanotubes: A review. Science of the total environment, 668: 566-576.

Kassem A, Ayoub GM, Malaeb L, 2019. Antibacterial activity of chitosan nano- composites and carbon nanotubes: a review. Science of the total environment, 668: 566-576. 
Khabashesku VN., \& Pulikkathara MX, 2006. Chemical modification of carbon nanotubes. Mendeleev Communications, 16(2): 61-66.

Li H, Fedorova OS, Grachev AN, Trumble WR, Bohach GA, Czuchajowski L, 1997. A series of meso-tris (Nmethyl-pyridiniumyl)-(4-alkylamidophenyl) porphyrins: Synthesis, interaction with DNA and antibacterial activity. Biochimica et Biophysica Acta (BBA)-Gene Structure and Expression, 1354(3): 252-260.

Liu S, Ng AK, Xu R, Wei J, Tan CM, Yang Y, Chen Y, 2010. Antibacterial action of dispersed single-walled carbon nanotubes on Escherichia coli and Bacillus subtilis investigated by atomic force microscopy. Nanoscale, 2(12): 2744-2750.

Ma R, Hu J, Cai Z, Ju H, 2014. Facile synthesis of boronic acid-functionalized magnetic carbon nanotubes for highly specific enrichment of glycopeptides. Nanoscale, 6: 3150-3156.

Mocan L, Ilie I, Matea C, Tabaran F, Kalman E, Iancu C, Mocan T, 2014. Surface plasmon resonance-induced photoactivation of gold nanoparticles as bactericidal agents against methicillin-resistant Staphylococcus aureus. International journal of nanomedicine, 9: 1453.

Mondal A, Basu R, Das S, Nandy P, 2011. Beneficial role of carbon nanotubes on mustard plant growth: an agricultural prospect. Journal of Nanoparticle Research, 13(10): 4519.

Onbaşı1ı D, Altuner EM, Çelik GY, 2011. Mnium marginatum Özütlerinin antimikrobiyal aktivitesi, Kastamonu Üniversitesi Orman Fakültesi Dergisi, 11 (2): 205-208.

Sah, U., Sharma, K., Chaudhri, N., Sankar, M., \& Gopinath, P. (2018). Antimicrobial photodynamic therapy: Single-walled carbon nanotube (SWCNT)-Porphyrin conjugate for visible light mediated inactivation of Staphylococcus aureus. Colloids and Surfaces B: Biointerfaces, 162, 108-117.

Salam, M. A., \& Burk, R. (2017). Synthesis and characterization of multi-walled carbon nanotubes modified with octadecylamine and polyethylene glycol. Arabian Journal of Chemistry, 10, S921-S927.

Seo Y, Hwang J, Kim J, Jeong Y, Hwang MP, Choi J, 2014. Antibacterial activity and cytotoxicity of multiwalled carbon nanotubes decorated with silver nanoparticles. International Journal of Nanomedicine, 9: 4621.

Sokolov VI, Stankevich IV, 1993. The fullerenes - new allotropic forms of carbon: molecular and electronic structure, and chemical properties. Russian Chemical Reviews, 62(5): 419.

Vecitis CD, Zodrow KR, Kang S, Elimelech M, 2010. Electronic-structure-dependent bacterial cytotoxicity of single-walled carbon nanotubes. ACS nano, 4(9): 5471-5479.

Wang JT, Chen C, Wang E, Kawazoe Y, 2014. A new carbon allotrope with six-fold helical chains in all-sp 2 bonding networks. Scientific reports, 4: 4339.

Zardini HZ, Amiri A, Shanbedi M, Maghrebi M, Baniadam M, 2012. Enhanced antibacterial activity of amino acids-functionalized multi walled carbon nanotubes by a simple method. Colloids and Surfaces B: Biointerfaces, 92: 196-202. 